\title{
SUBCORNEAL PUSTULAR DERMATOSIS IN A 47-YEAR-OLD WOMAN
}

\author{
Niken Ernaningtyas \\ Nana N. Jayadi \\ Herry E. J. Pandaleke
}

\author{
Bagian Ilmu Kesehatan Kulit dan Kelamin \\ Fakultas Kedokteran Universitas Sam Ratulangi Manado \\ Email: nick_noelita@yahoo.co.id
}

\begin{abstract}
Abstrak: Subcorneal pustular dermatosis (SPD) adalah penyakit inflamasi kulit yang jarang dan kronik-rekuren. Penyakit ini umumnya didapatkan pada wanita usia diatas 40 tahun dengan etiologi belum diketahui. Gambaran klinis yang khas berupa pustul atau vesikel yang dengan cepat berubah menjadi pustul di atas dasar kulit eritematosa, menyebar periferal, central healing, dan menyembuh meninggalkan area eritematosa berbentuk polisiklik disertai munculnya lesi baru. Lesi mengenai area intertriginosa, batang tubuh, dan daerah fleksural ekstremitas. Kami melaporkan kasus seorang perempuan usia 47 tahun dengan keluhan lepuh di hampir seluruh tubuh sejak setahun lalu. Lepuh mudah pecah dan meninggalkan erosi. Status dermatologis menunjukkan generalisata makula eritematosa et hiperpigmentasi, multipel, diskret, ukuran lentikular-plakat; vesikel multipel dan pustul diatasnya; dan pustul yang pecah dengan erosi dan krusta. Pada pasien dilakukan anamnesis, pemeriksaan laboratorium, serta biopsi kulit. Pemeriksaan Gram lepuh menunjukkan hanya terdapat leukosit PMN. Laboratorium darah lengkap normal, hitung eosinofil $1,9 \%$, hitung limfosit $24,3 \%$, LED $70 \mathrm{~mm} / \mathrm{jam}$, dan IgE total $831.000 \mathrm{IU} / \mathrm{mL}$. Pemeriksaan histopatologik menunjukkan spongiosis, lepuh subkorneal berisi fibrin, neutrofil, sedikit eosinofil di epidermis. Pada dermis tampak superficial perivascular inflammatory infiltration (neutrofil, limfosit, sedikit eosinofil). Pada kasus ini, diagnosis ditegakkan berdasarkan anamnesis, pemeriksaan fisik, dan pemeriksaan histopatologik yang khas untuk SPD.
\end{abstract}

Kata kunci: Subcorneal pustular dermatosis, pemeriksaan histopatologik

\begin{abstract}
Subcorneal pustular dermatosis (SPD) is a pustular eruption which is rare, chronic, and recurrent. This condition is commonly found in women over the age of 40 years with unknown etiology. It is characterized with symmetrical pustules/vesicles that quickly develop to pustules on erythematous skin with peripherally spreading. The pustules undergo central healing leaving polycyclic, erythematous areas in which new pustules arise. The lesions typically involve the intertriginous areas, trunks, and flexor of limbs. We reported a case of a 47-year-old woman with blisters and pustules all of the body surface since a year ago. The blisters ruptured easily and became erosions. The dermatological status indicated generalized erythematous hyperpigmented macules which were multiple, discrete, lenticular-plaques in size, multiple vesicles with pustules on it, and ruptured pustules leaving erosions as well as crusted areas. Anamnesis, physical examination, laboratory examinations, and a skin biopsy was performed. The Gram staining of the blister showed only PMN leukocytes. Normal CBC, eosinophil $1.9 \%$, lymphocyte $24.3 \%$, elevated ESR $70 \mathrm{~mm} /$ hour, total $\mathrm{IgE} 831.000 \mathrm{IU} / \mathrm{mL}$. The histopathological examination indicated spongiosis, subcorneal blister consisting of fibrin, neutrophils, and few eosinophils in the epidermis. The dermis revealed superficial perivascular inflammatory infiltration (neutrophils, lymphocytes, some eosinophils). These findings were typical for SPD. Conclusion: This case was diagnosed as subcorneal pustular dermatosis based on anamnesis, physical examination, and a histopathological examination.
\end{abstract}

Keywords: subcorneal pustular dermatosis, histopathological examination 
Subcorneal pustular dermatosis (SPD), also known as Sneddon-Wilkinson disease, is an uncommon, chronic, relapsing pustular eruption with histopathologically characterized by subcorneal pustule that contains neutrophils. ${ }^{1}$ This disease was first described in 1956 by Sneddon and Wilkinson. Its etiology remains unkown. ${ }^{1,2}$ Typically, the patient has a history of a relapsing symmetrical sterile pustular eruption involving the intertriginous areas, trunks, and flexor aspects of the limbs. Scalp is almost never affected, nor are the mucous membranes, palms, and soles. ${ }^{1,2}$

There is no racial predilection so far, however, many cases have been reported among the whites, Africans, Japanese, and Chinese. ${ }^{1}$ This disease is more frequently in females than in males $(4: 1){ }^{3}$ especially in the age group of 40 years or more. ${ }^{4}$ This disease occurs more rarely during childhood. ${ }^{5}$

We reported a case of subcorneal pustular dermatosis in a 47-year-old woman. This was the first case reported from the Dermatovenereology Department of Prof. Dr. R. D. Kandou Hospital Manado.

\section{CASE REPORT}

A 47-year-old woman was admitted to the Dermatovenereology Department in May 5th, 2013 with a history of relapsing pustular eruption involving the trunk, flexoral proximal extremities, and groin since a year ago. She noted that the onset was on her axillar areas and then the eruption spreaded to the inframammary folds, sometimes with mild pruritus, but there were no other associated symptoms. The patient reported that some blisters had arisen within a few hours, ruptured in a few days, and left erosions covered by thin crust. She had a history of atopic dermatitis, while her mother suffered from asthma. There was no history of drug allergy.

Physical examination revealed multiple pustules that tended to coalesce forming circinate or serpiginous pattern, and flaccid bullae filled with clear fluid on the erythematous skin of the trunk, groin, as well as on the upper and lower extremities. Within few days the pustules ruptured easily leaving erosions and superficial crust. The eruption spreaded peripherally with central healing. Healed lesions presented recidual hyperpigmentation without any trophic alteration. New pustules arised across the previously affected areas (Figure 1).

The laboratory examination showed normal complete blood count, eosinophil count $1.9 \%$, lymphocyte count $24.3 \%$, elevated erithrocyte sedimentation rate 70 $\mathrm{mm} /$ hour, and elevated total IgE 831,000 $\mathrm{IU} / \mathrm{mL}$. Blood ureum, serum creatinine, liver function test, fasting blood sugar, and HbA1c were within normal limits. The differential diagnoses of this patient were subcorneal pustular dermatosis and pemphigus foliaceus. A punch biopsy of a lesion on the upper arm was carried out.

The histopathological examination showed spongiosis, subcorneal blister consisting of fibrin, neutrophils, and few eosinophils in the epidermis. The dermis revealed superficial perivascular inflammatory infiltration consisting of neutrophils, lymphocytes, and some eosinophils (Figure 2). The Gram staining of the blister revealed PMNs, but none of positive/ negative Gram cocci, spores, or budding cells. Moreover, the Giemsa staining showed only PMNs.

\section{DISCUSSION}

Subcorneal pustular dermatosis is a benign inflammatory skin disease and characterized by remission and exacerbation that may last for 5-8 years. ${ }^{2,5}$ This disease is classified as neutrophilic dermatoses. ${ }^{6,7}$

The dermatological feature of SPD is a small flaccid pustule or vesicle that becomes pustular and forms crops over a few hours either on normal or erythematous skin. ${ }^{1,2,6}$ The pustules are superficial and often merge, forming annular, circinate, or serpiginous patterns. The eruption often 
spread peripherally with central healing and fades leaving post inflammatory pigmentary changes without atrophy or scar. ${ }^{1,2,8}$ The interval between flare-ups alternating with quiescent phases varies from a few days to several weeks. It has a tendency to locate in the flexural areas of the trunk and limbs, and rarely on the palms and soles, albeit, it never affect the face and scalp. There is no systemic symptom. ${ }^{1,2}$

The pathogenesis of this condition is still obscure ${ }^{1,2}$ and no infectious agents have been identified. ${ }^{1,6}$ Immunological mechanisms have also been implicated. ${ }^{9}$ Several diseases have been described in association with SPD, including $\operatorname{Ig}$ A paraproteinemia (up tp $40 \%$ cases) ${ }^{3}$ and myeloproliferative disorders especially multiple myeloma. ${ }^{1,3,10}$ The onset of this disease may occur after years, therefore, prolonged follow-up is needed. ${ }^{11,12}$

Other various systemic disorders that can be found with SPD were pyoderma gangrenosum, ulcerative colitis, Crohn's disease, Ig $\mathrm{G}$ paraproteinemia, $\mathrm{CD} 30^{+}$ anaplastic large-cell lymphoma, non small cell lung cancer, apudoma, rheumatoid arthritis, hyperthyroidism, and mycoplasma pneumonia infection. Further associated reported cases are multiple sclerosis, Sjögren syndrome, chronic lymphocytic leukemia, bullous pemphigoid, morphea, and marginal zone lymphoma. ${ }^{1,3,10}$ None of the previously known associations was present in this patient.

The histopathological examination reveals subcorenal pustule with neutrophils and few eosinophils. The epidermis beneath the pustule shows minimal changes and perhaps slight intracellular edema. ${ }^{3,11}$ Older lesions may contains acantholytic cells and superficial blood vessels with non-specific mixed inflammatory cell infiltration consisting of polymorph neutrophils and mononuclear cells in the dermis. $^{3}$ In this patient, the histopathological findings showed spongiosis and subcorneal blister consisting of fibrin, neutrophils and few eosinophils in the epidermis. The dermis revealed superficial perivascular inflammatory infiltration consisting of neutrophils, lymphocytes, and some eosinophils. These findings were consistent with SPD.

Direct immunofluorescent (DIF) studies in SPD are negative. There were some reported cases with clinical features resembled SPD and intraepidermal deposit of Ig A. The target of these $\operatorname{IgA}$ autoantibodies was desmocollin 1, ${ }^{1,10}$ and this disease was classified as SPD type IgA pemphigus. However, we did not perform immunoflourescence.

Sulfones are the primary treatment for SPD. Dapson is the most effective in dose of 50-150 mg daily. ${ }^{1}$ Although dapson has a slower response than in dermatitis herpetoformis, it leads usually in complete remission. ${ }^{11,12}$ Some patients have responded better to sulfapyridine therapy (1-3 g daily). Systemic corticosteroids are less effective but they have been used successfully. Additional treatments include retinoids (etretinate or acitretin) and PUVA or narrow band UVB. Colchicine and minocycline have also been useful in anecdotal reports. The use of immunobiological drugs such as infiximab and etarnecept have been reported with good result. ${ }^{13-15}$ This patient was treated with oral diaminodiphenylsulfone (dapson) $100 \mathrm{mg}$ daily and improved fairly.

SPD is a benign condition but it may recur over many years with remissions varying over many years from days to months. The general condition of the patient is not affected unless there is an associated immune dysfunction disorder.

\section{CONCLUSION}

We reported a case of a 47-year-old woman with blisters and pustules all of the body surface since a year ago. The dermatological status indicated generalized erythematous hyperpigmented macules which were multiple, discrete, lenticularplaques in size, multiple vesicles with pustules on it, and ruptured pustules leaving erosions as well as crusted areas. The Gram staining of the blister showed only PMN leukocytes. The histopatho- 
logical examination indicated spongiosis, subcorneal blister consisting of fibrin, neutrophils, and few eosinophils in the epidermis. The dermis revealed superficial perivascular inflammatory infiltration (neutrophils, lymphocytes, some eosinophils). These findings were typical for SPD. The patient was treated with oral diaminodiphenylsulfone (dapson) $100 \mathrm{mg}$ daily and improved fairly.
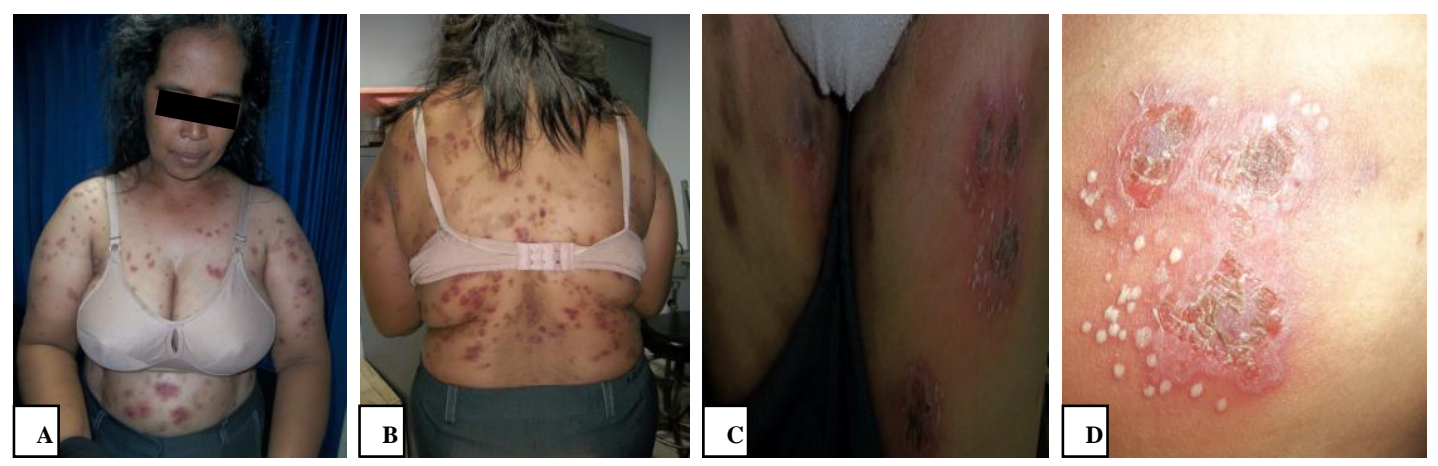

Figure 1. Multiple pustules that tended to coalesce forming a circinate or serpiginous pattern, flaccid bullae filled with clear fluid on the erythematous skin of the trunks, groin and upper and lower extremities. Pustules ruptured easily in a few days leaving erosions and superficial crust

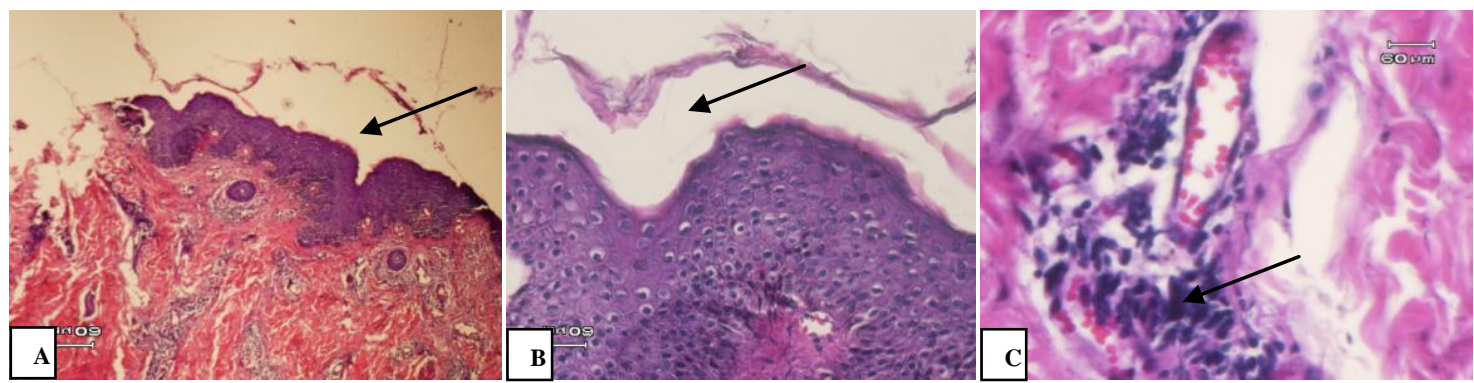

Figure 2. Histopathological images of subcorneal pustules. A, Subcorneal pustule below the stratum corneum (arrow) (HE, 4x). B, Subcorneal pustule (arrow) (HE, 10x). C, Many neutrophils (arrow) below the stratum corneum (HE, 40x)

\section{REFERENCES}

1. Trautinger F, Honingsmann H. SubCorneal Pustular Dermatosis (Sneddon Wilkinson Disease). In: Goldsmith LA, Katz SI, Gilchrest BA,Paller AS, Leffel DJ, Wolff K, editor. Fitzpatrick's Dermatology in General Medicine (8th ed.). New York: McGraw-Hill, 2012; p. 383-5.

2. Wojnarowska F, Venning VA. Immunobullous diseases. In: Burns $\mathrm{T}$, Breathnach S, Cox N, Griffiths C, editors. Rook's Textbook of Dermatology (8th ed.). London: Blackwell Publishing Ltd., 2010; p.
40.1-40.62.

3. Calonje JE, Brenn T, Lazar AJ, McKee PH, editors. McKees's Pathology on the Skin. Edinburg: Elsevier, 2012. p. 180 218.

4. Scalvenzi M, Palmisano F, Annunziata MC, Mezza E, Cozzolino I, Costa C. Subcorneal pustular dermatosis in childhood: A case report and review of the literature. Case report in Dermatological 2013 (internet). http://dx.doi.org/10.1155/2013/424797

Available from: Medicine http://www.hindawi.com/journals/cridm/ 2013/424797/ 
5. Paller AS, Mancini AJ, editors. Hurwitz Clinical Pediatric Dermatology (4th ed.). Edinburg: Elsevier Saunders, 2011.

6. Stone M, Brassard A. Neutrophilic dermatoses: Part I. Dermatology Rounds. 2003;2(1):1-6.

7. Bonamigo RR, Razera F, Olm GS. Neutrophilic dermatoses-Part I. An Bras Dermatol. 2011;86(1):11-27.

8. Brassard A, Stone M. Neutrophilic dermatoses: Part II. Dermatology Rounds. 2003;2(2):1-6.

9. Başak PY, Akkaya VB, Karahan N, Ceyhan AM. Subcorneal pustular dermatosis at the site of healed herpes zoster infection: Wolf's isotopic response. J Turk Acad Dermatol. 2009;3(3):93303c:1-4.

10. Ratnarathorn M, Newman J. Subconeal pustular dermatosis (SneddonWilkinson disease) occurring in association with nodal marginal zone lymphoma: A case report. Dermatology Online Journal. 2008;14(8):1-15.

11. Razera F, Olm GS, Bonamigo RR. Neutrophilic Dermatoses-Part II. An Bras Dermatol. 2011;86(2):195-211.
12. Laifaoui JIA, Guillen E, Worret JI, Ring J. A case of subcorneal pustular dermatosis (Sneddon-Wilkinsondisease) not responding to dapsone: therapeutic alternatives. Acta Dermatoven APA. 2003;12(3):109-11.

13. Voigtlander C, Lu M, Schuler G, Hertl M. Infliximab (antitumornecrosis factor alpha antibody). A novel, highly effective treatment of recalcitrant subcorneal pustular dermatosis (Sneddon-Wilkinson disease). Arch Dermatol. 2001;137:1571-4.

14. Bonifati C, Trento E, Cordiali FP, Muscardin L, Amantea A, Carducci M. Early but not lasting improvement of recalcitrant subcorneal pustular dermatosis (Sneddon-Wilkinson disease) after infliximab therapy: relationships with variations in cytokine levels in suction blister fluids. Clin Exp Dermatol. 2005;30: 662- 5.

15. Berk DR, Hurt MA, Mann C, Sheinbein D. Sneddon-Wilkinson disease treated with etanercept: report of two cases. Clin Exp Dermatol. 2009; 34(3):347-51. 